\title{
HUBUNGAN IKAN PELAGIS DENGAN KONSENTRASI KLOROFIL-A DI LAUT JAWA
}

\section{INTERRELATIONSHIPS BETWEEN PELAGIC FISH AND CHLOROPHYLL-A IN THE JAVA SEA}

\author{
Kamaluddin Kasim, Setiya Triharyuni dan Arief Wujdi \\ Pusat Penelitian Pengelolaan Perikanan dan Konservasi Sumber Daya Ikan \\ Teregistrasi I tanggal: 22 September 2013; Diterima setelah perbaikan tanggal: 03 April 2014; \\ Disetujui terbit tanggal: 08 April 2014 \\ E-mail: kamalu_fish00@yahoo.com
}

\begin{abstract}
ABSTRAK
Klorofil-a banyak ditemukan pada fitoplankton dan menjadi indikator kesuburan perairan. Keberadaan fitoplankton ditandai dengan kandungan klorofil-a yang tinggi dan diikuti oleh keberadaan zooplankton yang akhirnya mempengaruhi keberadaan organisme perairan lainnya seperti ikan pelagis kecil maupun ikan pelagis besar sebagai suatu rantai makanan. Interaksi antara konsentrasi klorofil-a terhadap keberadaan dan konsentrasi ikan pelagis di Laut Jawa belum banyak diketahui. Penelitian ini dimaksudkan untuk mengetahui hubungan interaksi antara klorofil-a terhadap konsentrasi ikan pelagis. Penelitian dilakukan dengan mengumpulkan data runtun waktu hasil tangkapan beberapa jenis pelagis besar dan kecil yang didaratkan di PPI Pekalongan tahun 2007-2011 serta data runtun waktu konsentrasi klorofil-a dari perairan utara Jawa yang diperoleh dari informasi sekunder. Metode analisis korelasi linear sederhana (bivariate correlation) digunakan untuk mengetahui ada atau tidaknya pengaruh antar variabel klorofil-a dan konsentrasi ikan pelagis. Hasil penelitian menunjukkan bahwa ikan layang (Decapterus russelli) paling nyata mendapat pengaruh dari konsentrasi klorofil-a $(\mathrm{P}<0,05)$ dan berkorelasi positif terhadap konsentrasi klorofil-a dengan nilai koefisien korelasi $(r)$ sebesar 0,56 , sedangkan ikan pelagis lainnya berkorelasi negatif. Ikan tongkol (Euthynnus affinis) posisinya menempati rantai makanan paling tinggi sebagai pemangsa, mempunyai korelasi positif $(r=0,5)$ terhadap Rastrelliger kanagurta dan $r=$ 0,56 terhadap Amblygaster sirm.
\end{abstract}

\section{KATA KUNCI: Ikan pelagis, klorofil-a, Laut Jawa}

\begin{abstract}
Chlorophyll-a is a light-absorbing pigment that can be found in photosynthetic organisms such as algae and phytoplankton. The evidence of phytoplankton that indicated by high contents of chlorophyll-a may followed the evidence of zooplankton and other micro aquatic organism as a food chain component. An overview of interrelationships between chlorophyll-a and pelagic fishes in the waters around Java Sea have not much investigated. The research was attempted to study the interaction between chlorophyll-a abundance and the abundance of small and large pelagic as well as relationship among small and large pelagic as prey-predators component. Research conducted by collecting time series catch data of small and large pelagic species landed at PPI Pekalongan during the period of 2006-2012, as well as the data of chlorophyll-a abundance through previous research studies. The results showed that layang (Decapterus russelli) was the most significant species that positively correlated to abundance of chlorophyll-a $(P<0.05)$ with value of $r=0.6$. while others pelagic species have negative correlation. As a predator species, tongkol (Euthynnus affinis) was positively correlated ( $r=0.5)$ to the abundance of banyar (Rastrelliger kanagurta) as well as juwi (Amblygaster sirm) with $r$ value 0.56 .
\end{abstract}

KEYWORDS: Pelagic fish, chlorophyll-a, Java Sea

\section{PENDAHULUAN}

Sumberdaya ikan pelagis kecil di perairan Laut Jawa telah dieksploitasi sejak tahun 1980-an (Potier \& Sadhotomo, 1994). Sejak munculnya alat tangkap purse seine, exploitasi menjadi semakin intensif dan berpengaruh terhadap perubahan komposisi jenis ikan yang tertangkap dan bergesernya area fishing ground (Atmaja et al., 2003).
Disebutkan pula bahwa pada periode 1985 -1990, nilai biomasa sumber daya ikan di Laut Jawa sebesar 120.000 ton dengan laju pertumbuhan populasi ikan pelagis sebesar 54.800 ton. Sedangkan pada periode 1991-2001, peningkatan nilai biomasa pelagis besar dan kecil mencapai dua kali lebih besar dari periode sebelumnya, dengan laju petumbuhan sebesar 69.900 ton selama 10 tahun. 
Terdapat 16 jenis sumberdaya ikan pelagis kecil yang tertangkap di Laut Jawa dimana enam jenis diantaranya memberikan kontribusi lebih dari $90 \%$ total hasil tangkapan. Keenam jenis tersebut yakni layang (Decapterus russellli), layang deles (Decapterus macrosoma), selar (Selaroides leptolepis), bentong (Selar crumenophthalmus), banyar/kembung lelaki (Rastrelliger kanagurta), siro/lemuru (Amblygaster sirm) dan tembang/juwi (Amblygaster sirm).

Daerah penangkapan ikan di Laut Jawa mengalami pergeseran sepanjang tahun dan dipengaruhi oleh musim. Sebagai contoh, ikan layang deles lebih banyak tertangkap pada bulan September sampai dengan Februari di bagian timur Laut Jawa dan Selat Makassar, ikan banyar melimpah pada bulan Juni sampai dengan Agustus di bagian barat Laut Jawa dan Laut Cina Selatan, ikan siro lebih berlimpah pada bulan Desember hingga Mei sepanjang tahun (Suwarso et al., 2004). Ikan pelagis besar seperti tenggiri (Scomberomorus commerson) di Laut Jawa umumnya melimpah pada bulan April dan November (Syukron, 2000). Ikan pelagis kecil di Laut Jawa umumnya ditangkap menggunakan pukat cincin (purse seine) dan gill net. Menurut Mahiswara et al. (2011), sebagaian besar perikanan pukat cincin berpangkalan di utara Jawa dan 51\% diantaranya terdapat di Jawa Tengah dengan basis utama di Pekalongan dan Juwana. Jumlah trip kapal pukat cincin cenderung menurun dari tahun ke tahun dimana pada tahun 1986 rata-rata trip sebesar 9,1 trip/kapal/tahun namun menurun drastis menjadi 2,3 trip/kapal/tahun pada tahun 2010 (Sadhotomo \& Atmadja, 2012). Tekanan eksploitasi penangkapan yang intensif pada sumberdaya ikan pelagis kecil dapat berdampak pada kestabilan populasi ikan pelagis besar sebagai satu kesatuan komponen makanan dalam struktur rantai makanan.

Perubahan lingkungan pada suatu wilayah daratan akibat aktivitas antropogenik dapat mempengaruhi ketersediaan unsur hara yang mendorong peningkatan ketersediaan klorofil-a dan konsentrasi fitoplankton. Selanjutnya kondisi ini meningkatkan kesuburan perairan (Bakun, 1996). Keberadaan zooplankton berupa kopepoda menjadi faktor penting keberadaan ikan pelagis dalam perairan serta tergantung pada ketersediaan fitoplankton atau kesuburan perairan yang dapat diindikasikan oleh tingkat kandungan klorofil-a (Ogawa \& Nakahara, 1979). Adnan (2010) melaporkan terdapat hubungan antara konsentrasi ikan tongkol dan konsentrasi klorofil-a di perairan Kalimantan Timur.

Gambaran mengenai interaksi antara ikan pelagis kecil sebagai mangsa ( prey) dan pelagis kecil sebagai pemangsa (predator) serta pengaruh klorofil-a terhadap keberadaan dan konsentrasi ikan pelagis di Laut Jawa belum banyak diketahui. Penelitian ini dimaksudkan untuk mengetahui hubungan interaksi antara klorofil-a terhadap konsentrasi ikan pelagis serta interaksinya dengan pelagis besar sebagai pemangsa dan pelagis kecil sebagai mangsa di Laut Jawa.

\section{BAHANDANMETODE}

Data yang digunakan pada penelitian ini berasal dari data primer dan data sekunder. Data primer berupa identifikasi dan komposisi jenis ikan yang didaratkan serta wawancara dengan nakhoda dan ABK kapal pukat cincin. Wawancara dimaksudkan untuk mengetahui cara pengoperasian alat tangkap, lokasi daerah penangkapan ikan, dan musim penangkapan ikan. Data sekunder dikumpulkan dari buku bakul (pengumpul) ikan dan Statistik Perikanan dari Pelabuhan Perikanan Nusantara (PPN) Pekalongan, meliputi data produksi bulanan (tahun 2007-2012) beberapa jenis ikan pelagis, lokasi daerah penangkapan, komposisi hasil tangkapan dan upaya penangkapan dengan menggunakan pukat cincin. Data tersebut merupakan data bulanan (monthly data) tahun 2007-2011. Data klorofil-a dikumpulkan secara bulanan dari tahun 2007-2008 dari hasil penelitian sebelumnya (Adnan, 2008).

Analisis data dilakukan dengan mengurutkan data runtun waktu hasil tangkapan ikan pelagis dominan yang didaratkan di PPI Pekalongan setiap bulan selama tahun 2007 sampai dengan tahun 2011. Untuk mengetahui interaksi antara hasil tangkapan ikan dengan konsentrasi klorofil-a dilakukan uji korelasi dan regresi linear dengan bantuan software R. Persamaan regresi sederhana (Walpole, 1992) sebagai berikut:

$$
\begin{aligned}
& y=a+b x \\
& a=y-b x \\
& b=\frac{n \sum x y-\left(\sum x\right)\left(\sum y\right)}{n \sum x^{2}-\left(\sum x\right)^{2}}
\end{aligned}
$$

Keterangan:

$$
\begin{aligned}
& \mathrm{y}=\text { hasil tangkapan } \\
& \mathrm{x}=\text { konsentrasi klorofil-a } \\
& \mathrm{a}=\text { intersep } \\
& \mathrm{b}=\text { slope/kemiringan } \\
& \mathrm{n}=\text { jumlah data }
\end{aligned}
$$

\section{HASIL DAN BAHASAN}

\section{HASIL}

\section{Komposisi Hasil Tangkapan dan Lokasi Penangkapan}

Jenis ikan layang (Decapterus russelli) mendominasi hasil tangkapan ikan pelagis kecil yang didaratkan di PPN Pekalongan antara tahun 2007-2009 dan tahun 2011 sebesar 37\%-59\% dari total produksi ikan pelagis kecil. 
Pada tahun 2010, hasil tangkapan ikan pelagis kecil didominasi oleh jenis lemuru (Amblygaster sirm) sebesar 47\%. (Gambar 1).

Terdapat lima jenis ikan pelagis kecil yang dominan didaratkan di PPN Pekalongan dalam tahun 2007-2011. Jenis paling dominan (37-59\%) yaitu ikan layang (Decapterus russelli), diikuti oleh lemuru (Ambligaster sirm) sebesar
17-47\%, jenis ikan campuran antara 5-14\%, ikan tembang (Sardinella fimbriata) antara 4-14\% dan jenis banyar (Rastrelliger kanagurta) sebanyak 3-6\%.

Pada periode tersebut, terdapat kecenderungan menurun bagi lima jenis ikan pelagis kecil yang dominan didaratkan yang tertangkap menggunakan pukat cincin (Gambar 2).
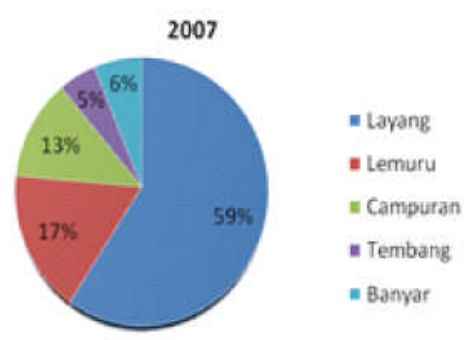

2009

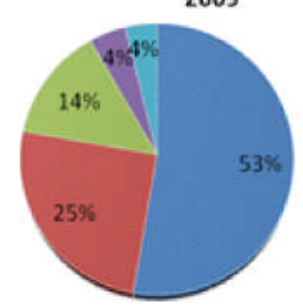

- Layang

= Lemuru

= Campuran

nembang

= Banyar

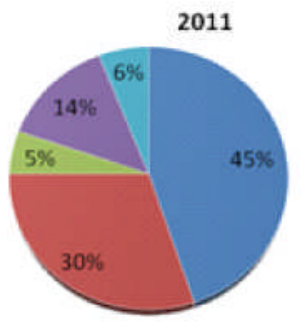

- Layang

- Lemuru

= Campuran

- Tembang

= Banyar

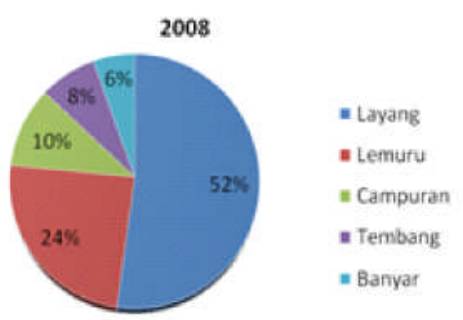

2010

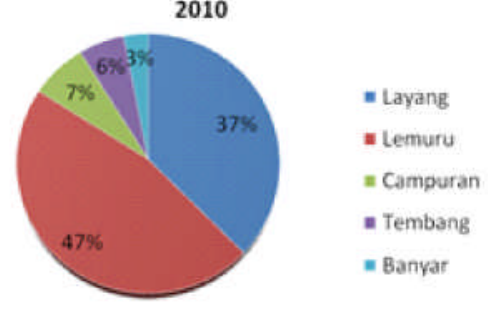

Gambar 1. Lima jenis ikan pelagis kecil dominan didaratkan di Pekalongan tahun 2007-2011.

Figure 1. The five dominant species of small pelagic fish were landed at Pekalongan during 2007-2011.

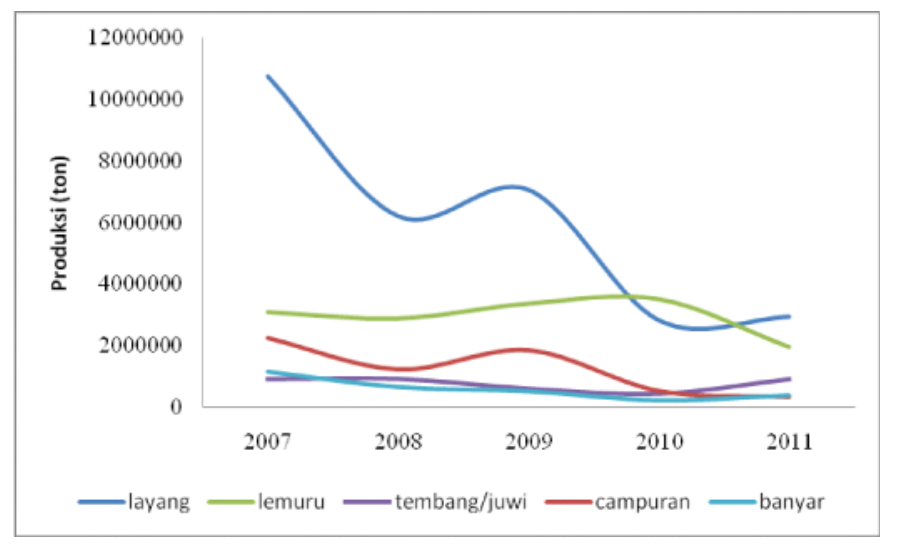

Gambar 2. Tren lima jenis hasil tangkapan pelagis kecil yang didaratkan di Pekalongan periode 2007 - 2011

Figure 2. Trend of five dominant pelagic species were landed at Pekalongan during 2007-2011 


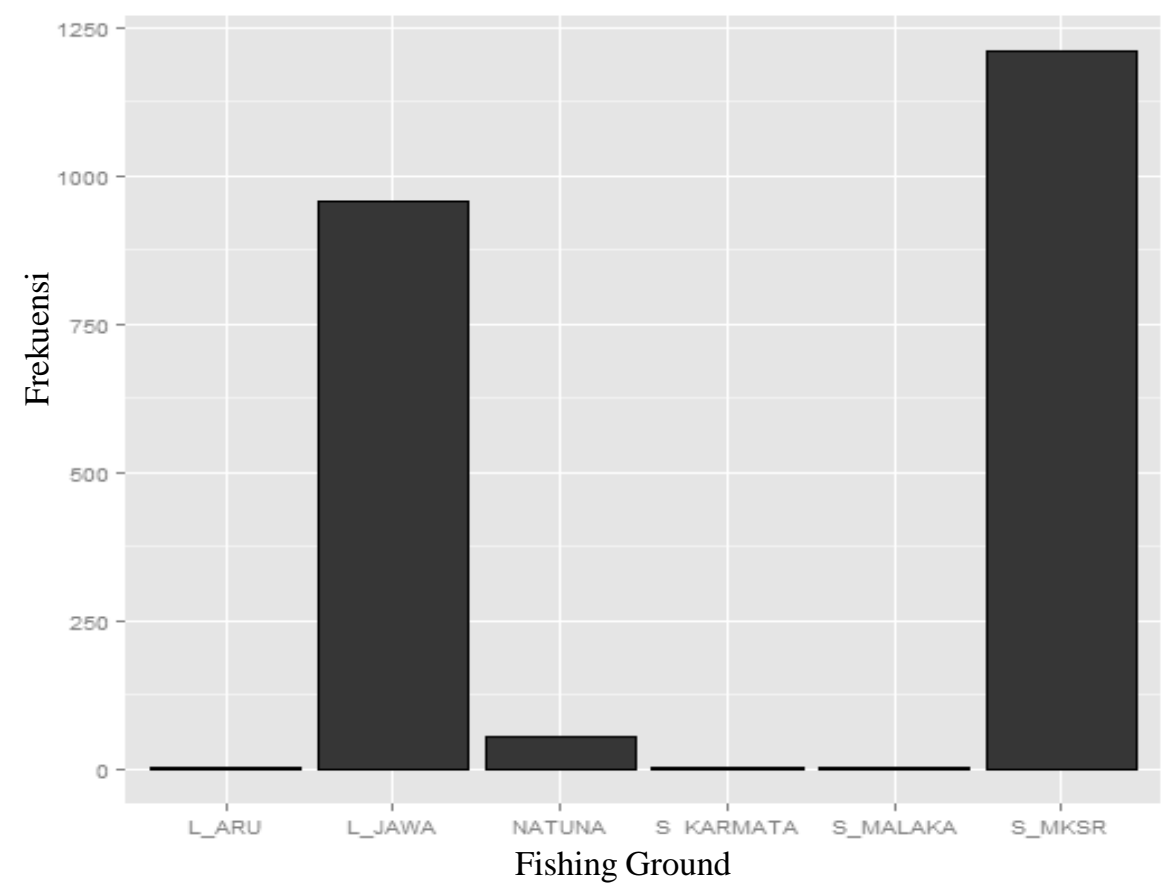

Gambar 3. Intensitas penangkapan berdasarkan daerah penangkapan kapal yang mendaratkan hasil tangkapannya di PPN Pekalongan periode tahun 2007-2011.

Figure 3. Fleet intensity based on fishing ground location during the period of 2007-2011.
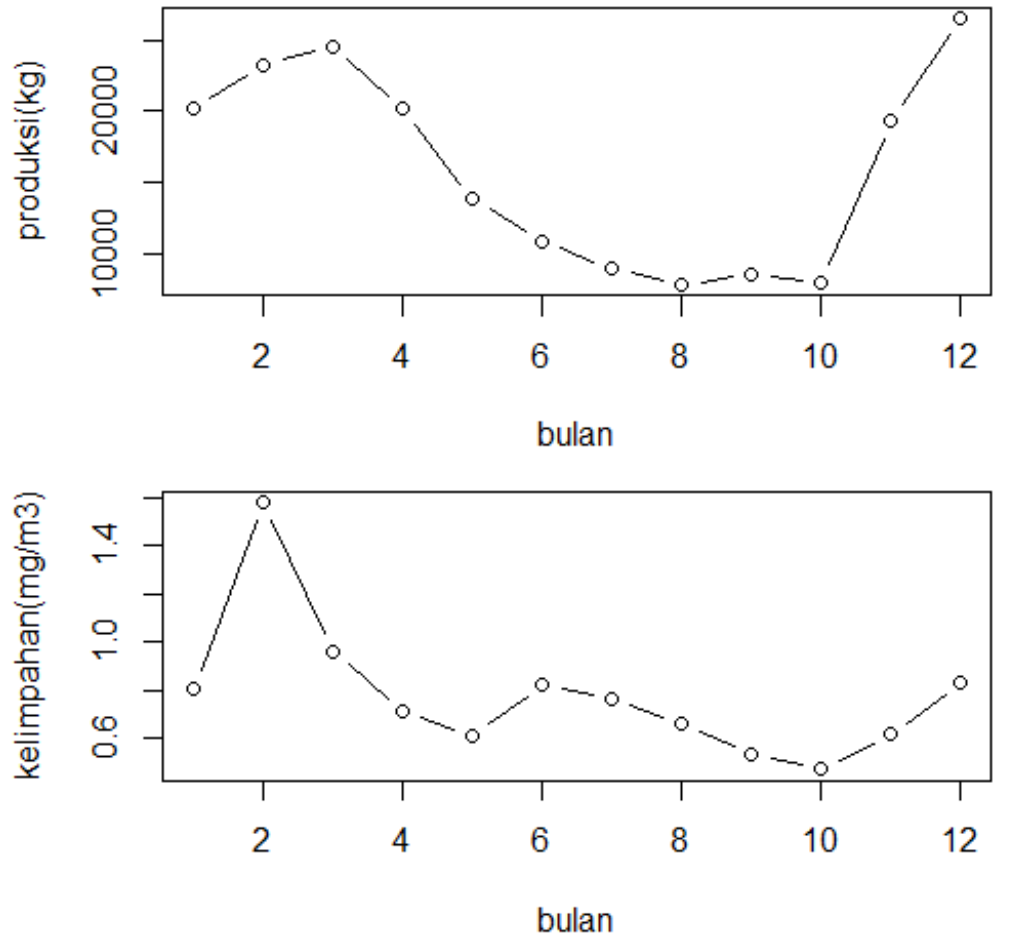

Gambar 4. Pola musim penangkapan ikan layang (D. russelli) (A) dan konsentrasi klorofil-a (B) di Laut Jawa tahun 2007-2008. (Data klorofil-a bersumber dari Adnan, 2008).

Figure 4. Seasonal catch pattern of Indian Scad (D. Russelli) (A) and chlorophyll-a abundance's pattern (B) in Java Sea during 2007-2008 (chlorophyll-a data were taken from Adnan, 2008). 

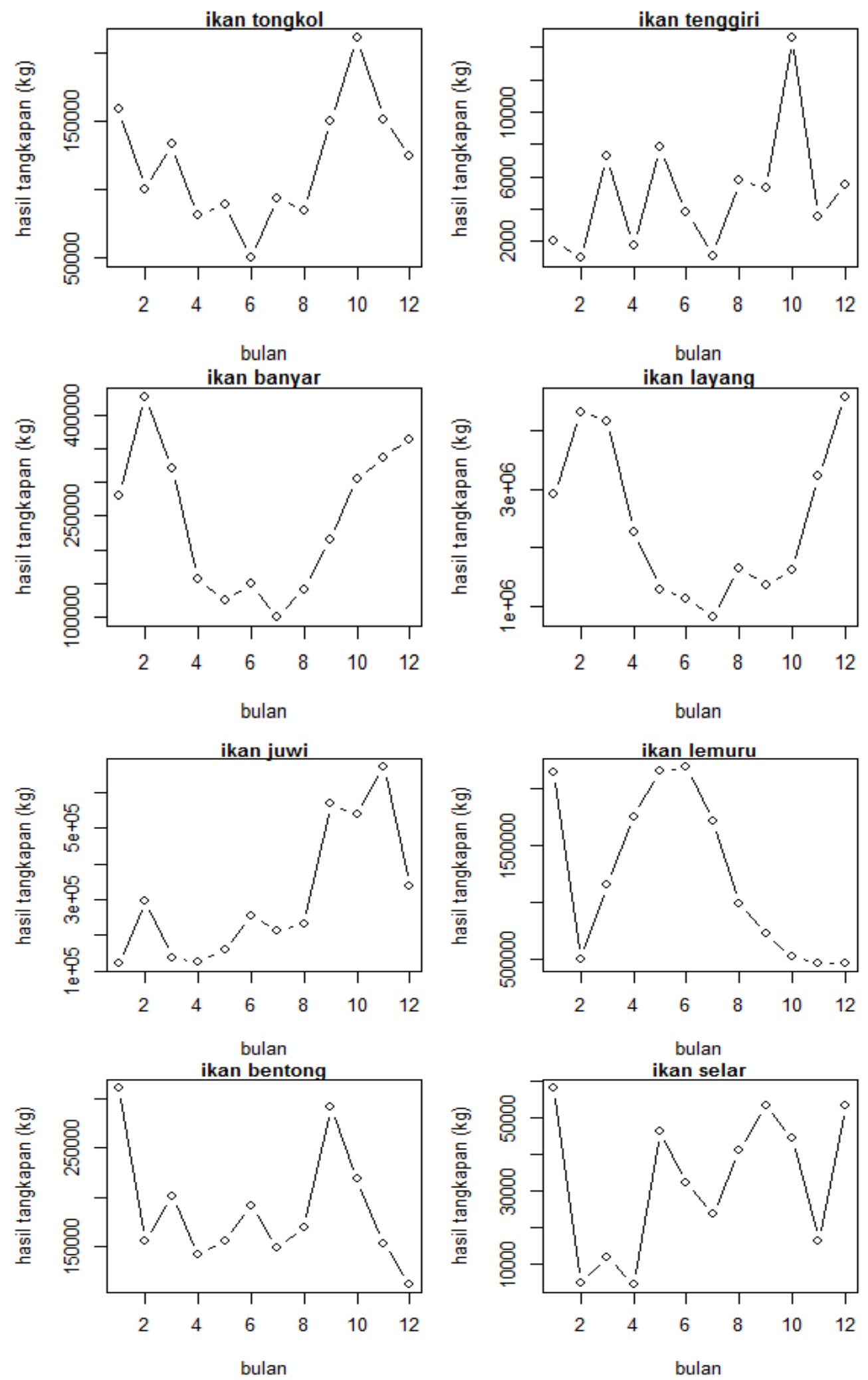

Gambar 5. Pola musim tangkapan beberapa jenis ikan pelagis besar dan kecil yang didaratkan di PPI Pekalongan pada tahun 2007-2011

Figure 5. Catches fluctuation of large and small pelagic species landed in Pekalongan landing station during 2007-2011. 
Lokasi daerah penangkapan yang intensif didominasi pada daerah Selat Makassar kemudian wilayah perairan Laut Jawa dan Laut Natuna (Gambar 3). Hasil analisis runtun waktu memperlihatkan bahwa kecenderungan upaya penangkapan bergeser ke arah timur yakni Selat Makassar dan sebagian Laut Flores

\section{Fluktuasi Hasil Tangkapan dan Kandungan Klorofil-a}

Kandungan klorofil-a memiliki pola fluktuasi musiman yang sama dengan konsentrasi ikan layang (Decapterus russelli) sebagaimana ditunjukkan pada Gambar 4. Jenis ikan pelagis besar seperti tongkol dan tenggiri, serta pelagis kecil seperti banyar, selar, bentong dan juwi memiliki pola fluktuasi yang berbeda terhadap konsentrasi klorofil-a ( Gambar 5).
Pola musim tangkapan ikan layang secara signifikan dipengaruhi oleh konsentrasi klorofil-a pada selang kepercayaan $(\mathrm{p}<0,05)$ dengan nilai koefisien korelasi $r$ sebesar 0,56 (Tabel 1). Jenis ikan lainnya seperti ikan banyar, juwi/siro, lemuru, selar, bentong, dan tenggiri tidak mendapat pengaruh langsung $(P>0,05)$ dan berkorelasi negatif terhadap fluktuasi konsentrasi klorofil-a sebagaimana yang ditunjukkan oleh Tabel tersebut.

Pola hubungan antara hasil tangkapan beberapa jenis ikan pelagis dan konsentrasi klorofil-a di perairan Laut Jawa digambarkan sebagai berikut:

Tabel 1. Hasil uji korelasi dari model linear sederhana keterkaitan antara jumlah tangkapan ikan pelagis dan konsentrasi klorofil-a di Laut Jawa.

Table 1. Correlation test of simple linear model between catches and chlorophyll-a abundance in Java Sea

\begin{tabular}{llccl}
\hline \multicolumn{1}{c}{ Variabel terikat } & Variabel bebas & $\begin{array}{c}\text { Nilai korelasi } \\
\text { pearson }(\mathrm{r})\end{array}$ & Nilai P & Keterangan \\
\hline Ikan layang & Konsentrasi klorofil-a & 0,56 & 0,05 & Korelasi positif cukup erat \\
Ikan banyar & Konsentrasi klorofil-a & $-0,001$ & 0,99 & Korelasi negatif \\
Ikan juwi & Konsentrasi klorofil-a & $-0,3$ & 0,3 & Korelasi negatif \\
Ikan tenggiri & Konsentrasi klorofil-a & $-0,5$ & 0,09 & Korelasi negatif \\
Ikan tongkol & Konsentrasi klorofil-a & $-0,3$ & 0,3 & Korelasi negatif \\
Ikan selar & Konsentrasi klorofil-a & $-0,5$ & 0,09 & Korelasi negatif \\
Ikan lemuru & Konsentrasi klorofil-a & $-0,11$ & 0,7 & Korelasi negatif \\
Ikan bentong & Konsentrasi klorofil-a & $-0,2$ & 0,49 & Korelasi negatif \\
\hline
\end{tabular}
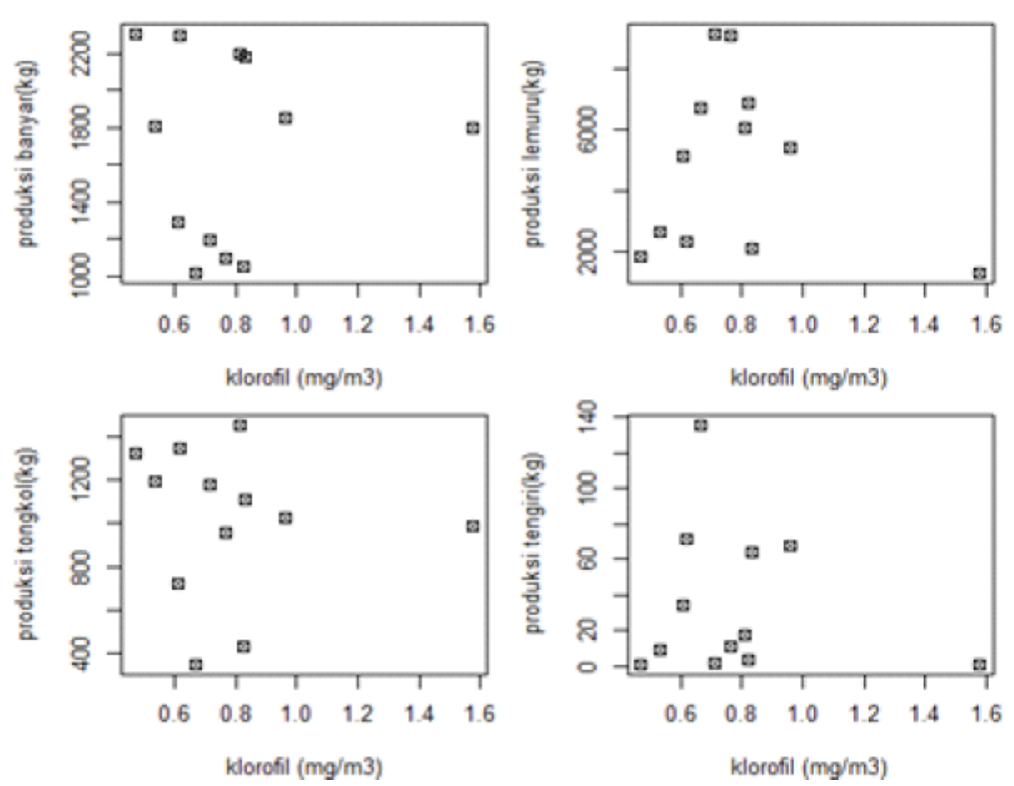

Gambar 6. Pola hubungan antara beberapa jenis ikan pelagis besar dan kecil terhadap konsentrasi klorofil-a di perairan Laut Jawa.

Figure 6. Relationship pattern of small and large pelagic catches and chlorophyll-a abundance in Java Sea. 


\section{Hubungan Ikan Mangsa-Pemangsa (predator-prey)}

Hubungan hasil tangkapan ikan pelagis besar (pemangsa) seperti tongkol dan tenggiri terhadap hasil tangkapan ikan pelagis kecil (ikan mangsa) seperti banyar, layang dan juwi terlihat jelas dalam hasil analisis ini. Tongkol dan tenggiri merupakan ikan pemangsa (predator) bagi ikan-ikan yang ukurannya lebih kecil seperti layang, banyar, maupun juwi/siro. Hubungan keduanya digambarkan pada Gambar 7.

Analisis runtun waktu hasil tangkapan ikan tongkol dan ikan banyar memiliki pola fluktuasi musiman yang sama sebagaimana ditunjukkan pada Gambar 7 dengan nilai koefisien korelasi $(r)$ sebesar 0.5. Hasil uji korelasi tersebut dirangkum pada Tabel 2 .
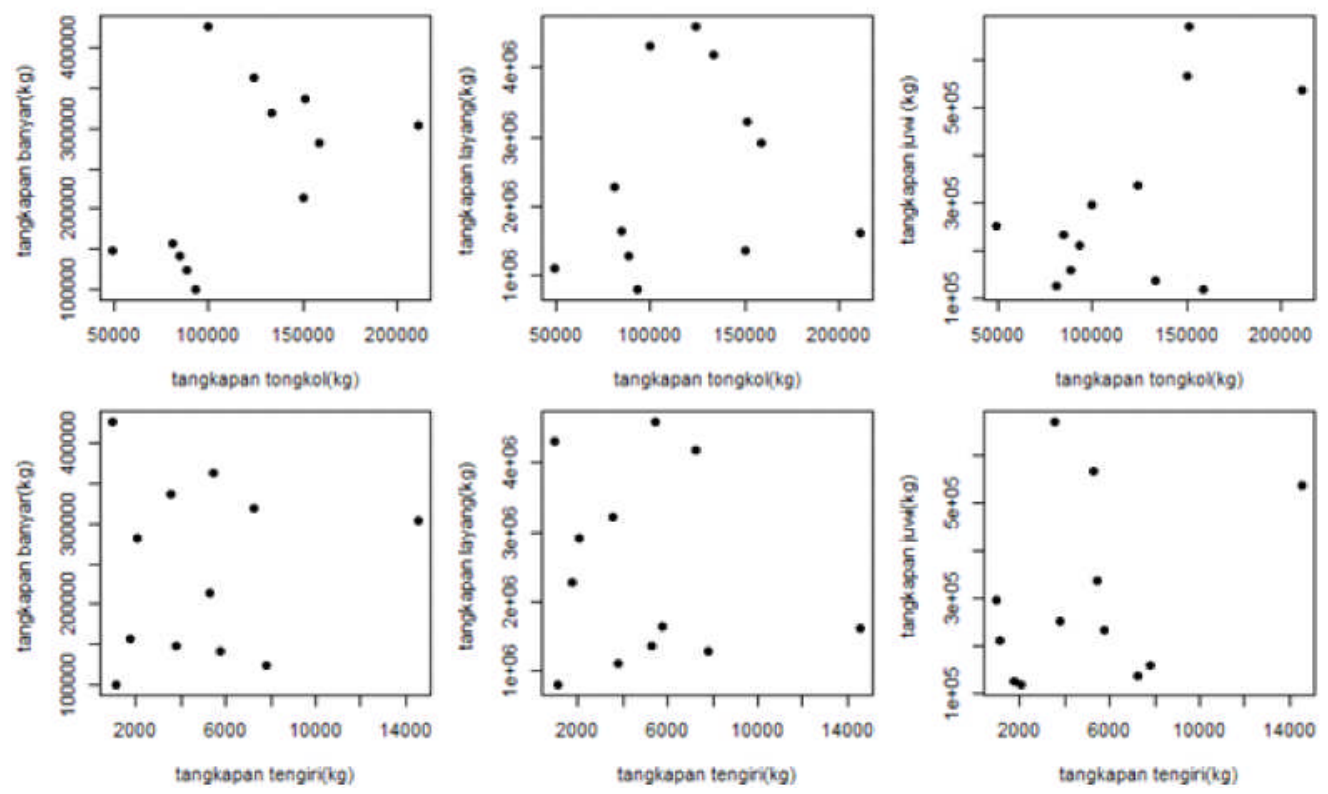

Gambar 7. Plot hubungan hasil tangkapan ikan pelagis besar (tongkol dan tenggiri) terhadap hasil tangkapan ikan pelagis kecil banyar, layang, dan juwi yang didaratkan di Pekalongan tahun 2007-2011

Figure 7. Catches of skipjack tuna and narrow-barred spanish mackerel plotted to catches of indian mackerel, indian scad, and goldstripe sardinella landed in Pekalongan, 2007-2011

Tabel 2. Hasil uji korelasi antara jumlah tangkapan ikan pelagis besar dan ikan pelagis kecil yang didaratkan di PPI Pekalongan tahun 2007-2011.

Tabel 2. Correlation test from simple linear model between large pelagic and small pelagic landed in Pekalongan, 2007-2011

\begin{tabular}{llccl}
\hline Variable terikat & Variable bebas & $\begin{array}{c}\text { Nilai korelasi } \\
\text { pearson }(\boldsymbol{r})\end{array}$ & $\boldsymbol{p}$-value & Keterangan \\
\hline Ikan tongkol & ikan banyar & 0,5 & 0,07 & Korelasi positif cukup erat \\
Ikan tongkol & ikan layang & 0,2 & 0,5 & Korelasi positif cukup erat \\
Ikan tongkol & ikan juwi & 0,56 & 0,049 & Korelasi positif cukup erat \\
Ikan tenggiri & ikan juwi & 0,32 & 0,3 & Korelasi negatif \\
Ikan tenggiri & ikan layang & $-0,15$ & 0,63 & Korelasi negatif \\
Ikan tenggiri & ikan banyar & 0,07 & 0,8 & Korelasi positif lemah \\
\hline
\end{tabular}

Berdasarkan plot hubungan antara konsentrasi ikan tongkol terhadap konsentrasi ikan pelagis kecil lainnya yakni banyar/kembung, layang dan juwi (Gambar 7), maka diketahui bahwa konsentrasi ikan juwi berpengaruh nyata terhadap ikan tongkol yang didaratkan $(\mathrm{P}<0,05)$. Nilai koefisien korelasi $r$ sebesar 0,56 menunjukkan adanya hubungan cukup erat antara hasil tangkapan ikan Juwi dan jumlah ikan tongkol yang didaratkan. Demikian pula dengan hasil tangkapan ikan banyar yang berkorelasi $r$ positif cukup erat terhadap jumlah hasil tangkapan ikan tongkol, sedangkan hasil tangkapan ikan tenggiri juga dipengaruhi oleh hasil tangkapan ikan juwi $(r=0,32)$ namun memiliki hubungan korelasi yang lemah. 


\section{BAHASAN}

Jumlah hasil tangkapan ikan layang meningkat pada bulan Oktober sampai dengan Februari (musim barat) bertepatan dengan kandungan klorofil-a yang tinggi pada periode Oktober hingga puncaknya pada bulan Februari (Gambar 4). Menurut Adnan, (2008), klorofil-a yang cenderung meningkat pada musim barat disebabkan oleh tingginya curah hujan pada saat itu yang diperkirakan membawa banyak nutrien yang berasal dari daratan atau pulau yang berada di sekitarnya. Untuk perairan Laut Jawa, curah hujan yang tinggi mampu membawa nutrien yang tinggi dari daratan Pulau Kalimantan dan Pulau Jawa yang dikenal banyak memiliki sungai-sungai besar dan bermuara di perairan Laut Jawa sebagai penyuplai utama nutrien dan massa air tawar. Hasil uji korelasi menunjukkan terdapat hubungan yang cukup erat antara pola fluktuasi bulanan konsentrasi klorofil-a dan fluktuasi hasil tangkapan ikan layang $(r=0,56)$.

Hardenberg (1955) mengemukakan munculnya stok ikan banyar di Laut Jawa terjadi pada akhir musim angin barat (west monsoon), dan beberapa minggu kemudian diikuti oleh kemunculan ikan layang. Lebih lanjut dijelaskan bahwa pada akhir musim monsoon timur muncul stok baru ikan banyar dan layang yang berasal dari arah barat yaitu laut Laut Cina Selatan dan dari barat daya Samudera Hindia.

Hasil tangkapan ikan layang yang memiliki pola fluktuasi yang sama terhadap konsentrasi kandungan klorofil-a di Laut Jawa mengindikasikan terdapat interaksi antara faktor lingkungan seperti ketersediaan makanan. Hasil pengamatan Hardenberg (1955) menemukan bahwa ikan pelagis kecil cenderung berkumpul pada daerah dengan densitas konsentrasi plankton yang tinggi sebagaimana yang terjadi di sepanjang pantai barat Kalimantan hingga pantai barat semenanjung Malaka. Keberadaan dan kandungan klorofil-a yang tinggi dalam suatu perairan menjadi salah satu indikasi tingginya konsentrasi fitoplankton dan zooplankton sebagai komponen produser dalam tingkatan rantai makanan tropik dan menjadi indikasi kesuburan perairan.

Studi mengenai keterkaitan kebiasaan makanan antara jenis ikan layang menjelaskan bagaimana keberadaan kedua jenis ikan ini sangat dipengaruhi oleh konsentrasi fitoplankton. Studi yang dilakukan oleh Jones \& Rosa (1962) mengemukakan bahwa ikan layang merupakan jenis pemakan plankton (plankton feeder). Fitoplankton dan zooplankton merupakan jenis makanan utama yang ditemukan dalam perut ikan layang. Ikan layang lebih menyukai zooplankton terutama dari jenis Calanus sp. (Silooy, 2013). Jenis makanan yang sama ini dapat menjelaskan mengapa jenis ikan ini membentuk pola musim hasil tangkapan yang cenderung sama dan memiliki keterkaitan erat terhadap konsentrasi kandungan klorofila pada perairan utara Jawa.

Keterkaitan antara jumlah hasil tangkapan antara ikan banyar dan ikan juwi terhadap hasil tangkapan ikan tongkol serta jumlah tangkapan ikan juwi terhadap hasil tangkapan ikan tenggiri mengindikasikan adanya hubungan interaksi antar spesies sebagai mangsa (prey) dan pemangsa (predator). Menurut Fischer, (1990) ikan tongkol dalam rantai makanan tingkatan trofik berperan sebagai pemakan ikan-ikan kecil, beberapa jenis cumi, jenis krustsea planktonik (megalops) dan larva Stomatopoda. Ditambahkan oleh Nootmorn (2008), sebanyak 38,8\% dari makanan ikan tongkol adalah ikan-ikan pelagis kecil, dan $60,7 \%$ adalah Cephalopoda.

\section{KESIMPULAN}

Jumlah tangkapan ikan layang (Decapterus russelli) di Laut Jawa berkorelasi positif dan erat terhadap kandungan klorofil-a. Jumlah tangkapan ikan pelagis lainnya seperti banyar, tongkol, juwi, tenggiri, selar dan bentong berkorelasi negatif terhadap konsentrasi klorofila.

Hasil tangkapan ikan pelagis besar seperti tongkol (Euthynnus affinis) dan tenggiri (Scomberomorus commerson) dipengaruhi oleh tangkapan pelagis kecil seperti banyar, layang dan juwi.

\section{DAFTAR PUSTAKA}

Adnan. 2008. Variabilitas hasil tangkapan ikan hubungannya dengan sebaran klorofil-a dan suhu permukaan laut data inderaja di perairan Kalimantan Timur. Skripsi: Sekolah Pasca Sarjana Institut Pertanian Bogor. $64 \mathrm{p}$.

Adnan. 2010. Analisis suhu permukaan laut dan klorofil-a data inderaja hubungannya dengan hasil tangkapan ikan tongkol (euthynnus affinis) di perairan Kalimantan Timur. Program Studi Penangkapan Fakultas Perikanan dan Ilmu Kelautan. Universitas Pattimura. Ambon. Jurnal Amanisal. 1 (1). 1-12 p.

Atmaja, S. B., Haluan, J. \& A. Fauzi. 2003. Pendugaan pertumbuhan bersih stok ikan pelagis di Laut Jawa dan sekitarnya. Buletin PSP.16 (2). 17-34 p.

Bakun, A. 1996. Patterns in the ocean: Ocean processes and marine population dynamics. California Sea Grant College System, National Oceanic and Atmospheric Adminstration in cooperation with Centro de Investigaciones Biologicas del Noroeste (La Jolla, Calif.). 257 p. 
Fischer, W. I. 1990. Fichas FAO de identificaçao de espécies para actividades de pesca. Guia de campo das espécies comerciais marinhas e de águas salobras de Moçambique. Publicaçao preparada em collaboraçao com o Instituto de Investigaçao Pesquiera de Moçambique, com financiamento do Projecto PNUD/FAO MOZ/86/030 e de NORAD. 424 p.

Hardenberg, J. 1955. A review of current knowledge of rastrelliger : behaviour, ecology, food, growth, migration, reproductions, systematics, synonym and distribution. Proceeding of Indo-Pacific Fisheries Council $6 t^{\text {h }}$ Session. 1-10.

Jones, S. \& H. Rosa Jr. 1962. Synopsis of biological data on the fishes of the genus Rastrelliger Jordan and Stark 1908 with an annotated Bibliography. Symposium on scombroid fishes Mandapam Camp Mumbai India: Marine Biological Association of India. 1190-1234.

Mahiswara, Natsir M. \& T. W. Budiarti. 2011. Standarisasi upaya penangkapan pukat cincin di Laut Jawa. Pusat Penelitian Pengelolaan Perikanan dan Konservasi Sumber Daya Ikan Badan Penelitian dan Pengembangan Kelautan dan Perikanan. Jurnal Penelitian Perikanan Indonesia. 17(4). 256 p.

Nootmorn, P. M. 2008. Stomach content of the large pelagic fishes in the Bay of Bengal. IOTC-2008-WPEB-11.

Ogawa, Y. \& T. Nakahara. 1979. Interrelationships between pelagic fishes and plankton in the coastal fishing ground of the Southwestern Japan Sea. Marine Ecology-Progress Series. 1. 115-122.

Potier, M., \& B. Sadhotomo. 1994. Seiners fisheries in Indonesia. In S. Potier (Eds.): Biodynex. Biology, Dynamics, Exploitation of Small Pelagic Fishes in the Java Sea. Jakarta. 49-66.

Sadhotomo, B. \& S. B. Atmadja. 2012. Sintesa kajian stok ikan pelagis kecil di Laut Jawa. Jurnal Penelitian Perikanan Indonesia. Pusat Penelitian Pengelolaan Perikanan dan Konservasi Sumber Daya Ikan. Badan Penelitian dan Pengembangan Kelautan dan Perikanan. 18(4). 229.

Silooy, F. D. http://isjd.pdii.lipi.go.id:http://isjd.pdii.lipi.go.id/ index.php/Search.html?act=tampil\&id=1346\&idc=33. Diunduh tanggal 22 Mei 2013.

Suwarso, Hariati, T., Sadhotomo, B., Atmaja, S. B., \& Wudianto. 2004. Musim penangkapan ikan pelagis kecil dalam Anonimus (ed). Musim penangkapan Ikan di Indonesia. Jakarta. Penebar Swadaya. 23-45.

Syukron, M. 2000. Analisis tingkat pemanfaatan dan musim penangkapan ikan tenggiri (Scomberomerus commerson) di Laut Jawa. Skripsi. Program Studi Ilmu dan Teknologi Kelautan Fakultas Ilmu Kelautan dan Perikanan Institut Pertanian Bogor. 2-35.

Walpole, R. 1992. Pengantar Statistika. Cetakan Ketiga. Jakarta: PT Gramedia Pustaka Utama. 